\title{
Isu-isu Strategis Penataan Otonomi Daerah
}

\author{
Nur Achmad Affandi
}

A narrow meaning of autonomous region has caused disintegration and has arisen local exclusivities. Meanwhile, autonomous region should improve democratization, public services, and comparative advantages and build credible governance.

D ari berbagai diskusi dengan kalangan birokrat, cendekiawan kampus, politisi, pekerja sosial/ aktivis LSM, dapat disimpulkan bahwa dalam memperbincangkan otonomi daerah -dengan pendekatan desentralistikmasyarakat sering terjebak pada "hanya" memperbincangkan masalah keuangan daerah (lebih khusus lagi yang bersumber dari Pendapatan Asli Daerah Sendiri/ PDAS). Umumnya, masyarakat kurang berminat terhadap isi aturan dan makna substansial dari otonomi daerah sebagaimana yang diatur dalam UU No. 22/1999 tentang Pemerintahan Daerah dan UU No. 25/1999 tentang Perimbangan Keuangan antara Pusat dan Daerah. Dalam 2 tahun pelaksanaan otonomi daerah, banyak dikeluhkan oleh masyarakat bahwa dengan pelaksanaan otonomi daerah masyarakat tidak merasakan kehidupan yang lebih baik tetapi justru banyak pungutan yang dilakukan oleh Pemerintah Daerah untuk membiayai pemerintahannya, dengan akuntabilitas yang masih rendah.

Kiranya sepakat bahwa partisipasi masyarakat dan birokrat - semua stakeholders - dalam otonomi daerah ditentukan oleh pemahamannya dalam hal tersebut, sehingga menjadi kewajiban bersama untuk membangun pemahaman yang benar dan komprehensif. Di tingkat manapun otonomi daerah dilaksanakan (Propinsi atau Kabupaten/Kota) seluruh elemen masyarakat mesti memahaminya dengan benar.

Pada awal mula reformasi hanya didorong oleh emosionalitas tanpa didasari plan for planning terlebih dahulu untuk memperoleh negotiate agreement dari seluruh komponen. Masyarakat dan juga pemerintah pada waktu itu tidak menyadari bahwa perubahan tidak dapat dihindari. Untuk itu seharusnya diperlukan adanya perubahan yang direncanakan agar reformasi atau perubahan mencapai tahapan dan sasaran yang tepat. Di pihak lain perlu kesadaran pula bahwa perubahan atau reformasi adalah suatu proses yang tidak saja membutuhkan tahap, tetapi juga waktu.

\section{Makna Otonomi dan Sejuta Harapan}

Pelaksanaan otonomi dengan UU No. 22/1999 dan UU No. 25/1999 memang tampak lebih tegas, pas dan nyata dengan pengertian asli otonomi, adalah: kebebas- 
an, kemandirian, self independence atau dispersion of power. Tetapi dikarenakan kita sedang bereuphoria dengan kebebasan setelah berpuluh-puluh tahun ada di dalam Pemerintahan Orde Baru yang monolitik sentralistik, makna otonomi dalam pengertian demokrasi lokal menjadi berubah makna. Di satu pihak pemerintah (pusat) memiliki kegamangan dengan makna otonomi yang sesungguhnya, di pihak lain masyarakat dan daerah-daerah memiliki aneka pengertian untuk memberikan makna kepada otonomi.

Otonomi dimaknakan sebagai kebebasan dalam arti seluas-luasnya, sehingga tidak memikirkan kebutuhan, kepentingan ataupun keterkaitan dengan daerah lain, bahkan keterikannya dengan Negara Republik Indonesia, yang terjadi kemudian maraknya keinginan-keinginan disintegrasi. Demikian juga otonomi dimaknakan sebagai kemandirian daerah yang terlalu berlebih-lebihan, sehingga menunjukkan adanya eksklusivisme daerah. Dalam hal ini otonomi sebatas dimaknakan sebagai aroganisme daerah. Sedangkan bagi pemerintah (pusat atau propinsi) dimaknakan masih sebatas pada administratif, bukan secara fisik dan fungsional. Tidak mengherankan, bila masih terlihat keengganan atau keterpaksaan pemerintah untuk memberikan kewenangan yang lebih besar kepada daerah-daerah. Otonomi masih sebatas dimaknakan sebagai desentralisasi administratif (fungsi pemerintah pusat dilaksanakan oleh pejabat/pegawai daerah) dari pada devolution (pemerintah pusat memberikan wewenang otonom kepada daerah untuk membuat keputusan sendiri dalam urusanurusan tertentu).

Dengan berbagai-bagai pemaknaan otonomi yang jauh dari makna sesungguhnya, tidaklah mengherankan apabila masih terjadi tarik menarik diantara keinginan dan harapan pemerintah puasat, propinsi dengan daerah-daerah. Juga menjadi tidak mengherankan, apabila saat ini tidak terjadi kompatibilitas antara pusat dan propinsi ataupun dengan kabupaten (kota) dan kabupaten (kota) lainnya. Bahkan di antara kelompok-kelompok masyarakat.

Inti dari pelaksanaan otonomi daerah adalah terdapatnya keleluasan pemerintah daerah (discretionary power) untuk menyelenggarakan pemerintahan sendiri atas dasar prakarsa, kreativitas dan peranserta aktif masyarakat dalam rangka mengembangkan dan memajukan daerahnya. Otonomi daerah tidak hanya berarti melaksanakan demokrasi di lapisan bawah, tetapi juga mendorong otoaktivitas masyarakat untuk melaksanakan sendiri apa yang dianggap penting bagi lingkungannya. Dengan berkembangnya pelaksanaan demokrasi daii bawah, maka rakyat tidak saja dapat menentukan nasibnya sendiri, melainkan yang utama adalah kebebasan dan kemandirian untuk berupaya memperbaiki kesejahteraannya, sesuai dengan kepentingan dan potensi daerahnya melalui berbagai aktivitas pembangunan.

Dalam penyelenggaraan otonomi daerah perlu lebih menekankan pada prinsip demokrasi, peran serta masyarakat, pemerataan dan keadilan, serta memperhatikan potensi dan keanekaragaman daerah. Sebagai daerah otonom, daerah mempunyai kewenangan dan tanggungjawab untuk menyelenggarakan kepentingan masyarakat berdasarkan prinsip keterbukaan, partisipasi masyarakat, dan pertanggungjawaban kepada masyarakat.

UU No. 22/1999 tentang Pemerintahan Daerah pasal 7 ayat (1) menyebutkan bahwa kewenangan daerah adalah seluruh bidang pemerintahan, kecuali: Politik Luar Negeri, Pertahanan Keamanan, Peradilan, Moneter dan Fiskal, Agama. Pasal 11 ayat (2) menyebutkan bahwa bidang pemerintahan yang wajib dilaksanakan oleh 
Daerah Kabupaten dan Daerah Kota meliputi: Pekerjaan Umum, Kesehatan, Pendidikan dan Kebudayaan, Pertanian, Perhubungan, Industri dan Perdagangan, Penanaman Modal, Lingkungan Hidup, Pertahanan, Koperasi, dan Tenaga Kerja.

Masyarakat menaruh harapan yang sangat besar adanya peningkatan kesejahteraan. Terwujudnya Otonomi Daerah secara penuh dan luas merupakan sarana untuk mencapai pemerataan daerah dan pencituan jurang ketimpangan ekonomi dan sosial antara wilayah kaya dan miskin dan antara wilayah yang sudah maju dan terbelakang. Dengan dikeluarkannya UU 22/ 1999 dan UU 25/1999, daerah akan memperoleh kewenangan yang lebih besar untuk mengatur rumah tangganya sendiri dan memperoleh perimbangan keuangan yang adil (yang dipastikan lebih besar), sehingga pada gilirannya mampu meningkatkan kesejahteraan warganya. Dalam menyikapi Otonomi Daerah, yang penting untuk dipersiapkan adalah memastikan dapat disusunnya perencanaan yang mantap dan menyeluruh dalam pemanfaatan dana pembangunan untuk meningkatkan kesejahteraan masyarakat sesuai dengan kewenangan yang dimiliki. Jika selama ini program pembangunan lebih banyak diukur dari segi efisiensinya saja (cost \& benefit ratio), maka Otonomi Daerah menuntut diterapkannya ukuran-ukuran lain yaitu keadilan dan pemerataan.

\section{Isu-isu Penataan Otonomi Daerah}

Dengan diundangkannya UU 22/1999 telah terjadi berbagai perubahan mendasar dalam pengaturan Pemerintah Daerah. Sebagai konsekwensi logis adalah perlunya dilakukan penataan terhadap elemen yang berkaitan dengan Pemerintah Daerah sebagai manifestasi dari otonomi daerah.
- Secara teoritis, ada 6 (enam) elemen utama yang membentuk Pemerintahan Daerah yaitu: 1) Adanya urusan otonomi yang merupakan dasar dari kewenangan daerah untuk mengatur dan mengurus rumah tangganya sendiri; 2) Adanya kelembagaan yang merupakan pewadahan dari otonomi yang diserahkan kepada daerah; 3) Adanya personil (pegawai) yang bertugas untuk menjalankan urusan otonomi yang menjadi isi rumah tangga daerah; 4) Adanya sumber-sumber keuangan untuk membiayai pelaksanaan otonomi daerah; 5) Adanya unsur perwakilan yang merupakan dari wakil-wakil rakyat yang mendapatkan legitimasi untuk memimpin penyelenggaraan pernerintahan daerah; 6 ) Adanya manajemen urusan otonomi yaitu penyelenggaraan otonomi daerah agar dapat berjalan secara efisien, efektif, ekonomis dan akuntabel.

Keenam elemen di atas secara terpadu merupakan suatu sistem yang membentuk Pemerintahan Daerah. Untuk itu, maka penataan Pemerintah Daerah akan selalu berkaitan dengan penataan keenam elemen di atas. Perıataan haruslah bersifat terpadu dan menyeluruh, karena pendekatan piecemeal yang dilakukan selama ini menghasilkan outcomes yang kurang optimal. Untuk dapat memberikan kontribusi yang optimal terhadap reformasi, maka diperlukan berbagai pemikiran secara sistematis untuk dituangkan dalam suatu agenda penataan pemerintahan daerah.

Tujuan utama dari penataan kewenangan (urusan otonomi), kelembagaan, personil, keuangan, perwakilan dan manajemen urusan otonomi tersebut adalah agar Pemerintah Daerah mampu menjalankan tugas pokok dan fungsinya secara ekonomis, efektif, efisien dan akuntabel dengan melibatkan partisipasi masyarakat dan bermuara pada peningkatan kesejahteraan masyarakat. Hal ini sejalan dengan alur 
pikir akademis yang berkembang secara universal bahwa Pemerintah Daerah (Pemda) dengan otonominya ditujukan untuk mencapai dua tujuan utama yaitu; tujuan politis dan tujuan administratif (Smith BC dalam bukunya Decentralisation, 1985 dan Rondinelli, Nellis and Cheema dalam bukunya Decentralisation in Developing Countries, 1984).

Tujuan politis akan memposisikan Pemda sebagai instrumen pendidikan politik di tingkat lokal yang secara agregat akan menyumbangkan pendidikan politik secara nasional sebagai elemen dasar dalam menciptakan persatuan berbangsa dan bernegara. Pemberian otonomi dan pembentukan institusi Pemda akan mencegah terjadinya sentralisasi dan mencegah kecenderungan sentrifugal dalam bentuk pemisahan diri. Adanya institusi Pemda akan mengajarkan kepada masyarakat untuk menciptakan kesadaran membayar pajak dan sekaligus memposisikan Pemda untuk mempertanggungjawabkan pemakajan pajak rakyat tersebut (no tax without representation). Tujuan administratif adalah mengisyaratkan Pemda untuk mencapai efisiensi, efektivitas dan ekonomis serta akuntabel dalam melaksanakan tugas pokok dan fungsinya. Pemda dituntut untuk hemat dalam memakai uang rakyat (pembayar pajak). Pemda yang boros akan. kehilangan legitimasi politik dari warganya dalam bentuk tidak terpilihnya lagi mereka untuk menjalankan mandat warga setempat. Proses tersebut akan terkristalisasikan dalam pemilihan umum di tingkat lokal.

Secara operasional, berbagai makna yang terkandung dalam konsep tersebut adalah:

1) Pengertian ekonomis terkandung makna, bagaimana Pemda mampu menjalankan urusan otonominya dengan berbagai pertimbangan eko-nomis yaitu memilih dari berbagai alternatif yang terbaik dari sudut total pembiayaan. Gambaran yang paling aktual dari pengertian ekonomis tersebut adalah adanya kemampuan Pemda untuk membuat pilihan antara sektor publik atau sektor privat atau kombinasi antara keduanya (public private partnership) dalam menjalankan urusan otonominya. Tujuan ekonomis ini akan memberikan citra hilangnya kesan pemborosan dalam penyelenggaraan pemerintahan daerah baik dalam kegiatan rutin maupun pembangunan. Kesan better value for money akan mengental. Ini berarti bahwa Pemda akan selalu bersikap kompetitif dalam upaya memberikan nilai tertinggi bagi setiap rupiah uang rakyat yang dipergunakan.

2) Pengertian efektif terkandung makna bahwa dalam menjalankan tugas pokok dan fungsinya Pemda dapat mencapai sasaran yang direncanakan. Untuk itu perlu disepakati terlebih dulu standar efektivitas yang diinginkan. Sasaran atau tujuan yang ingin dicapai oleh Pemda haruslah terukur dan ada standart yang jelas. Tujuan yang ingin dicapai adalah bahwa Pemda menjadi peka dalam menentukan tujuan atau sasaran dari setiap urusan otonomi yang dilaksanakan. Adanya sasaran yang jelas akan menunjukkan sejauhmana Pemda dapat menangkap aspirasi dan mengartikulasikan tuntutan (demand) dan dukungan (support) masyarakat daerah yang bersangkutan.

3) Pengertian efisiensi terkandung makna bahwa output yang dihasilkan dari setiap penyelenggaraan urusan otonomi tercapai dengan resources inputs yang minimal. Tujuan 'yang ingin dicapai adalah untuk menciptakan citra bahwa Pemda akan selalu hemat dalam mem- 
pergunakan resource (dana, pegawai, peralatan dan tata kerja (prosedur), dan lain-lain) dalam menjalankan tugas pokoknya.

4) Pengertian akuntabel terkandung makna bahwa Pemda mengutamakan kepentingan warganya dengan jalan mempertanggungjawabkan pelaksanaan otonominya kepada masyarakat melalui wakil-wakil rakyat dalam yurisdiksinya. Tujuan yang ingin dicapai adalah pendidikan politik masyarakat lokal yang pada gilirannya secara agregat akan menyumbangkan pendidikan politik secara nasional. Adanya pendidikan politik yang baik akan mencegah terjadinya gerakan sentrifugal (separatisme) dalam masyarakat (mungkin karena perbedaan etnis, agama, suku, bahasa maupun tingkat ekonomi).

\section{Beberapa Langkah Operasional}

Secara filosofis, adanya Pemda adalah untuk melayani kebutuhan masyarakat (public service). Berkait dengan otonomo daerah, maka konsekwensinya adalah bahwa urusan yang dilimpahkanpun seyogyanya berbeda pula antara satu daerah dengan daerah yang lainnya sesuai perbedaan karakter geografis dan demografis penduduknya. Untuk itu, analisis kebutuhan (need assesment) merupakan suatu keharusan sebelum urusan tersebut diserahkan ke suatu daerah otonom atau daerah menyatakan menerima otonominya. Upaya untuk mereaktualisasikan otonomi daerah merupakan langkah pertama dari reformasi Pemda.

Adanya reaktualisasi dalam distribusi urusan akan melahirkan langkah kedua yaitu bagaimana melembagakan urusanurusan tersebut. Lembaga akan mewadahi berbagai urusan yang pada gilirannya akan melahirkan struktur organisasi dan tata kerjanya. Berbagai alternatif dapat ditawarkan dalam aspek kelembagaan ini. Apakah kita akan memilih kelembagaan publik dalam pembentukan Dinas-dinas otonom, atau menyerahkan urusan tersebut kepada pihak swasta (privatisasi) atau kemitraan antara pihak Pemda dengan swasta (public private partnership). Tolok ukurnya adalah bagaimana urusan tersebut dapat terlaksana secara efektif, efisien, ekonomis dan akuntabel.

Langkah ketiga adalah penataan personil yaitu adanya pegawai yang akan menjalankan kelembagaan tersebut. $\mathrm{Ke}$ lemahan dari sistem kepegawaian Pemda dewasa ini adalah tidak kondusif untuk mencetak personil yang handal (profesional) yang mampu melahirkan gagasangagasan inovatif dengan keunggulan kompetitif dan komparatif sesuai tuntutan globalisasi. Sistem senioritas dan eselonisasi telah melahirkan birokrasi yang sibuk mengejar senioritas pangkat dan eselon yang sering tidak berhubungan dengan peningkatan kinerja. Sistem mutasi yang tidak atas dasar keahlian, namun lebih atas dasar "kepercayaan" akan menyebabkan personil memulai jabatan barunya dengan keahlian relatif dari nol. Dalam penentuan atau promosi jabatan, harus ada perpaduan antara senioritas dan kemampuan (capability). Adalah wajar personil yang senior dan mamp (capable) mendapatkan prioritas pertama, dan kemampuannya dibuktikan oleh serangkaian tes kemampuan yang diperuntukan untuk jabatan tersebut. Bila perlu lembaga tes independen dapat ditunjuk untuk melakukan seleksi tersebut. Apabila personil senior dan mampu tidak ada, maka harus ada kerelaan untuk memberikan kesempatan kepada personil yang yunior dan mampu. Argumennya adalah bahwa dalam era persaingan bebas ini, kita sangat memerlukan personil dengan ke- 
mampuan tinggi untuk memenangkan persaingan global yang tidak mengenal senioritas dan eselonering.

Dalam aspek keuangan, argumen utama adalah bahwa Pemda dalam menjalankan otonominya hendaknya didukung oleh adanya sumber-sumber keuangan yang memadai untuk membiayai otonominya. Kurangnya sumber keuangan akan menyebabkan Pemda akan mengurangi standard pelayanan yang diberikan dan apabila dibiarkan akan menciptakan externalities yang akan merugikan kepentingan nasional. Adanya masyarakat yang sakitsakitan karena rendahnya standar kesehatan akan menurunkan produktivitas nasional.

Dalam aspek perwakilan, keberadaan DPRD haruslah mampu menciptakan check and balance terhadap eksekutif daerah untuk menciptakan pemerindah daerah yang kompetitif dan inovatif serta bersih dari unsur KKN. UU 22/1999 telah memberikan peranan sentral kepada DPRD dalam menentukan jalannya pemerintah daerah ditandai dengan besarnya kewenangan DPRD dalam memilih dan menetapkan Kepala Daerah dan memposisikan Kepala Daerah untuk bertanggungjawab kepada DPRD. Dari ketentuan tersebut kita melihat besamya peranan yang diberikan UU 22/1999 kepada DPRD sebagai perwujudan kedaulatan rakyat.

Dalam aspek manajemen urusan, berbagai paradigma baru pengelolaan sektor publik telah muncul dan telah ditetapkan di berbagai negara di dunia. Pada dasamya manajemen sektor publik (termasuk pemerintah daerah) telah dituntut untuk meningkatkan efisiensi, efektivitas, ekonomis dan akuntabilitas dalam penyelenggaraan otonomi daerahnya. Berbagai pendekatan manajemen madem perlu dicemati, seperti privatisasi dan kemitraan serta beralihnya peran pemerintah dari penyedia (rowing) menjadi pengarah dan pemberdaya (steer- ing). Pendekatan governance telah mendudukkan pemerintah, masyarakat dan swasta untuk bersama-sama secara sinergi menyediakan pelayanan yang sebelumnya menjadi monopoli sektor publik (pemerintah) menuju ke arah kemitraan yang saling mendukung dan menguntungkan.

Untuk mengefektifkan pelaksanaan otonomi daerah yang memberikan manfaat nyata bagi masyarakat, maka perlu adanya penataaan kembali mengenai beberapa aspek berikut: urusan atau kewenangan, kelembagaan, personalia, keuangan, perwakilan dan manajemen dari Pemerintah Daerah yang ada sekarang dengan mengacu kepada tataran normatif sesuai dengan aturan-aturan baru dan tataran teoritis sebagai justifikasi akademisnya. Apapun bentuk penataan yang akan dilakukan haruslah mengacu pada benchmarking yang telah diuraikan di atas yaitu bahwa penataan tersebut hendaknya kondusif untuk membentuk Pemerintah Daerah yang efisien, efektif, ekonomis dan akuntabel yang bermuara pada pelayanan yang baik kepada masyarakat guna meningkatkan kesejahteraannya secara adil.

Keenam variabel tersebut merupakan pilar-pilar utama (soko guru) dari setiap bentuk pemerintah daerah. Penguatan terhadap keenam dimensi tersebut merupakan prerequisite dalam penguatan pemerintah daerah. Pendekatan yang bersifat peacemeal tidak akan memecahkan persoalan otonomi secara keseluruhan. Penguatan pada salah satu atau beberapa aspek dan melupakan aspek lainnya tidak akan pemah efektif menuntaskan penguatan (empowering) otonomi daerah secara keseluruhan.

Dari pendekatan sistem; keenam dimensi tersebut lebih merupakan suatu sistem yang terintegrasi yang saling tergantung dengan lainnya. Sebagai contoh; kalau hanya aspek urusan, kelembagaan, personil dan keuangan yang ditata dengan 
melupakan penguatan pada aspek perwakilan, akan menciptakan pemerintah daerah dengan akauntibilitas yang rendah karena lemahnya mekanisme check and balance di tingkat lokal. Absennya mekanisme check and balance akan menjadi pemantik (trigger) bagi mal-administrasi. Ini berarti pemerintah daerah gagal dalam mencapai tujuan politiknya sebagai medium pendidikan politik masyarakat.

Walaupun mungkin aspek distribusi urusan, kelembagaan, personil, keuangan, perwakilan telah ditata, namun manajemennya masih lemah maka output yang dihasilkan adalah adanya pemerintah daerah yang akauntabel namun boros dan tidak efisien dälam menjalankan tugas pokoknya.

\section{Catatan Akhir}

Dari uraian di atas jelas nampak keterkaitan satu dimensi dengan dimensi lainnya. Konsekuensinya dalam konteks penguatan otonomi adalah adanya penguatan secara holistic atas keenam dimensi tersebut. Secara empirik, kegagalan politik desentralisasi lebih disebabkan oleh adanya pendekatan yang bersifat parsial (piecemeaf) sehingga outcome dari desentralisasi sering sangat mengecèwakan elite yang memerintah dan menyebabkan mereka beralih kepada pilihan dekonsentrasi sebagai perpanjangan tangan dari pemerintah pusat.

Dengan pelaksanaan otonomi daerah yang luas dan nyata sebenarnya merupakan momentum yang sangat baik untuk memacu reformasi Pemda menuju Pemda yang efektif, efisien, ekonomis dan akuntabel. Namun perubahan yang diharapkan tidakiah berjalan secara mulus karena banyak sekali menuntut perubahan pola pikir, pola bertindak dan kemauan dari pihak Pusat maupun Daerah. Adalah sangat sulit untuk merubah pola berpikir daerah yang selama tiga dekade terpatronisasi dan terkooptasi oleh Pusat dan dalam waktu singkat dituntut untuk menjadi mandiri, penuh inisiatif dan menghilangkan ketergantungannya ke Pusat baik secara mental maupun finansial. Hal yang sama terjadi juga di jajaran birokrasi Pusat yang selama ini sudah terbiasa memposisikan diri sebagai "patro" dan menganggap Daerah sebagai "client" mereka, tiba-tiba menjadi kehilangan previlage, dan harus memposisikan diri dalam kesetaraan dengan Daerah. Beharvior \& attitude shifting tersebut yang kiranya membutuhkan waktu yang lama untuk merealisasikannya.

\section{Daftar Pustaka}

Alderter, H.F, 1964 Local Goverment in Developing Countries, New York, Mc Graw Hill.

David Osborn, 1986, Reinventhing Goverment, University Press, New York, USA.

Harun Alrasyid, 1999, Federalisme Mungkinkah bagi Indonesia, Jakarta, Kompas.

Fosep Riwu Kaho, 1997, Prospek Otonomi Daerah di Negara Republik Indonesia, Jakarta, Rajawali Press.

Undang-undang No. 22 Tahun 1999 tentang Otonomi Daerah.

Undang-undang No. 25 Tahun 1999 tentang Perimbangan Keuangan antara Pusat dan Daerah. 